\title{
Project ATAS - Ancient traps of the Adriatic Sea Objectives, obstacles and results with focus on the cultural and heritage tourism
}

\author{
Zrinka Mileusnić, University of Primorska, Faculty of Humanities
}

Projekt ATAS - Antične pasti jadranskega morja je rezultat sodelovanja štirih različnih projektnih partnerjev iz Hrvaške, Črne gore in Slovenije. Glavni cilj projekta je bil vzpostaviti mrežo standardiziranih turističnih produktov s poudarkom na podvodni dediščini Jadrana. V prispevku predstavljamo glavne cilje in rezultate projekta, vendar tudi opozarjamo na potencialne ovire z vidika kulturnega in dediščinskega turizma.

Ključne besede: podvodna dediščina, kulturni turizem, potapljaški turizem, promocija dediščine

Project ATAS - Ancient Traps of Adriatic Sea is the result of collaboration of four different project partners from Croatia, Montenegro and Slovenia. The main objective of the project was to establish a network of standardised tourist products with focus on underwater heritage of Adriatic. This paper presents the main project objectives and results, but also reminds of the potential obstacles from the perspective of the cultural and heritage tourism.

Keywords: underwater heritage, cultural tourism, diving tourism, promotion of heritage

Introduction

$\mathrm{P}$ roject ATAS (Ancient traps of the Adriatic Sea) is the result of partnership and common goals of four different partner institutions from three eastern Adriatic countries - Slovenia, Croatia and Montenegro, forming a public-private consortium. Under the coordination of the lead partner City of Mali Lošinj (Croatia), partners DF agencija d.o.o. za fotografiju i zastupanje u fotografiji (Croatia), University of Primorska (Slovenia) and Hidromont engeenering (Montenegro), have collaborated on the creation and the design of a multifaceted project proposal that has been rewarded the grant for its implementation through the EASME (Executive Agency tor Small and Medium-sized Enterprises of the European Commission) programme Implementation of the Eu- ropean Maritime and Fisheries Fund Work 2015 and the specific action Thematic touristic routes on underwater cultural heritage.

The main goal of the project consortium was to establish a common online platform with a set of standardised tourist products as the basis for creation of a network of similar Adriatic destinations with specific tourist products. The main objective of the creation of such a platform was to enable SMEs and other institutions to ease the promotion and visibility of similar small scale tourist products for the specific target audience, that could not be achieved by individual approach and without networking. Specific goal was to create tourist products for divers with the focus on the underwater heritage with additonal objectives of creating a cultural trail to increase the overall visibility of underwater heritage and

\footnotetext{
https://ec.europa.eu/easme/en/ancient-traps-adriatic-sea
} 
raise awareness of its preservation, of enhancing diversification in tourism offer, improving competitiveness of destinations, extending the season and ensuring greater sustainability for SMEs in the form of longer term employment.

Network of destinations, along with above mentioned promotion goals of tourist products, had an objective of raising awareness of european underwater heritage and creating synergies provoking more interest and reinforcing this specific cultural heritage as motive for travel, resulting with the creation of the product that comprised different types of tourism - diving and cultural tourism while creating a starting point, or initiatl cultural route, for the potential development of several cultural routes.

\section{Goals, obstacles and results}

For the implementation of the project partners have chosen four main destinations connected with their main activities: Mali Lošinj (Island of Lošinj, Croatia), Luka Prvić (Island of Prvić, Croatia), Izola (Slovenia) and Budva (Montenegro). The initial idea was developed by the partner in Prvić Luka (Croatia) who is involved in the swimming tourism network and is offering standardised products all over the world. ${ }^{2}$ The goal was to use the know-how and apply it to another type of tourism - diving tourism.

At all destinations diving tourism offer already exists through the activities of licensed diving clubs and in the form of different kind of diving activities, mainly focused on the leisure divers. That is why the product needed a specific subject or additional attractive content to make it different and recognisable. It was decided to include the underwater cultural heritage, based on the rapid increase of demand in production and consumption of heritage attractions in the frame of European cultural tourism.

At all chosen locations or in their vicinity, there are different underwater sites. Some of these sites are already exploited in the form of cultu-

SOURCE 6: https://www.swimtrek.com/

Greg Richards, »Production and consumption of European Cultural Tourism«. Annals of Tourism Research 23/2 (1996): 261-283. ral tourism but are still not well recognizable at European tourism market. In order to raise the identity of the future cultural-diving tourist products, the specific underwater heritage was chosen to be included - the underwater heritage of the Roman period. This choice was based on the fact that the lead partner - the City of Mali Lošinj has already been building its recognition on the European tourist market by promoting the underwater heritage Apoxyomen, a bronze statue o fan Greek athlete that sunk in the Roman period in the vicinity of the island. ${ }^{4}$ In order to promote it in the best possible way and make it accessible to the greatest number of visitors, the city built a contemporary museum, presenting a broader story about the heritage while displaying only the original statue as the only exhibit.

This experience added another elelmet to the product - the need of combinig the underwater heritage in situ (accessible only by diving) with the obligatory visit to the museum, and thus enabling the comprehensice experience and understanding of underwater heritage. This idea was in line with several international documents $^{6}$ dealing with the promotion of cul-

$4 \quad$ Zrinka Ettinger Starčić, Underwater archaeological sites of the Lošinj Archipelago (Mali Lošinj, 2013)

SOURCE 2 http://www.unesco.org/new/en/culture/themes/underwater-cultural-heritage/200I-convention/ (1.5.2017); SOURCE 3 Manual for Activities directed at Underwater Cultural Heritage. Eds. Thijs J. Maarleveld, Ulrike Guérin, Barbara Egger. UNESCO publications (2013). http:/www.unesco.org/new/en/ culture/themes/underwater-cultural-heritage/publications-resources/publications/ (1.5.2017)

6 Zrinka Mileusnić, »Cultural tourism and cultural tourists - basic concepts.« in Lazar, Irena (ed.). Project AS. Archaeology for all. Revival of the Archaeological park Simonov zaliv. Project Manual (Koper: Založba Univerze na Primorskem, 2016), I04-108; ICOMOS, »Mednarodna listina o kulturnem turizmu in Doktrina $\mathrm{I}$ : Mednarodne listine ICOMOS, ed. Jovo Grobovšek (Ljubljana: združenje ICOMOS/SI, 1999), 6I-67; ICOMOS. "Listina o interpretaciji in predstavitvi območij kulturne dediščine." Doktrina 2: Mednarodne listine in dokumenti ICOMOS, uredil: Jovo Grobovšek, (Ljubljana: Združenje ICOMOS/SI, 2008), 45-53; ICOMOS, »Mednarodna listina o ohranjanju in upravljanju arheološke dediščine (Lausannska listina) in Doktrina I: Mednarodne listine ICOMOS, ed. Jovo Grobovšek (Ljubljana: združenje ICOMOS/SI, 1999), 45-50; SOURCE 2 http://www.unesco.org/new/en/culture/ themes/underwater-cultural-heritage/200I-convention/ (I.5.2017); SOURCE 3 Manual for Activities directed at Underwater Cultural Heritage. Eds. Thijs J. Maarleveld, Ulrike Guérin, Barbara Egger.UNESCO (2013); Role of Museums in Education and Cultural Tourism Development: Policy Brief. UNESCO (2012), Kyev; Ted 
tural heritage and the necessity of the active intergration of museums in the field of cultural tourism.

Creating the idea of uniting several destinations in one promotional platform and combininig diving and specific cultural heritage seemed as an ideal setting for creation of new tourist products at the beginning. Two of destinations have archeological parks suitable for tourists and amateur divers. Museums are also present in all destinations or in their vicinity, as well as historical background. Also, all destinations are located in growing tourism region of Adriatic and are in proximity to major European markets for scuba tourism like Germany and Austria. The destination in Slovenia included the Archaeological park in the Simon's bay in Izola. At this specific destination many of the previous activities have included building contents and infrastructure for the promotion of the Roman maritime villa and its surrounding area. These included the underwater archaeological park, interpretational centre and biking and hiking heritage trails in the surrounding area. The inclusion od the site in the promotional platform, international networking with similar destinations and creation of the specific tourist products in collaboration with local SME's was a logical next step in its development. ${ }^{7}$ Besides the already mentioned underwater heritage, the island of Lošinj has

Silberberg, »Cultural tourism and business opportunities for museums and heritage sites «. Tourism Management 16/5 (1995): 361-365. Lazar, Irena, (ed.). Project AS. Archaeology for all. Revival of the Archaeological park Simonov zaliv. Project Manual (Koper: Založba Univerze na Primorskem, 2016); Irena Lazar, »Short description of the project and project collaborators. « In Lazar, Irena (ed.). Project AS. Archaeology for all. Revival of the Archaeological park Simonov zaliv. Project Manual, Koper (Založba Univerze na Primorskem, 2016): 8-15; Irena Lazar, Mateja Ravnik, Katarina Šmid, »New contents fort he vi-

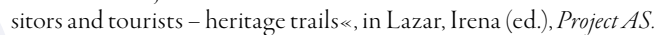
Archaeology for all. Revival of the Archaeological park Simonov zaliv. Project Manual (Koper: Založba Univerze na Primorskem, 2016), 166I83; Irena Lazar, Zrinka Mileusnić, »Projekt AS in arheologija kot kulturni turizem. Studia Universitatis Hereditati 3/1 (2015), 75-85; Zrinka Mileusnić, »Cultural tourism and cultural tourists - basic concepts. «In Lazar, Irena (ed.), Project AS. Archaeology for all. Revival of the Archaeological park Simonov zaliv. Project Manual (Koper: Založba Univerze na Primorskem, 2016), 104-108; Zrinka Mileusnić, »The Project AS and archaeology as a cultural tourism.« In Lazar, Irena (ed.), Project AS. Archaeology for all. Revival of the Archaeological park Simonov zaliv. Project Manual (Koper: Založba Univerze na Primorskem, 2016), 16-17. salso an existing underwater historical park, ${ }^{8}$ as well as many other underwater sites with a great potential for their promotion and inclusion in the cultural tourism products.' However, several problems have arised in locations in island of Prvić in Croatia and in Montenegro.

The island of Prvić has no underwater heritage sites in the exact vicinity. This problem was solved by creating the list of existing archaeological sites, published at the site of Croatian Ministery of Culture and mentioned in the publications. ${ }^{1 \circ}$ Also, a Municipal museum in Biograd na moru was included in the package. ${ }^{\text {II }}$ For a final selection of sites, local diving clubs were consulted. The problem that arose was the existance of a protective measure that includes a yearly concession for the diving clubs and diving at these sites. Although the measure has the main goal to enhance the collaboration in protection, monitoring and promotion of the underwater heritage, the local diving clubs interpreted the measure as financially non attrative, so they rather than paying for it decide not to dive at the pprotected sites. On the other hand the measure is limited in number so it often happens that foreign diving clubs pay for it but do not dive at these locations. Since these problem scan not be solved with a single project and are to be solved on the national level, in the frame of the project financi-

8 The underwater historical park presents different attractions from different historical periods but it is arising questions about the authenitcity. Since it has been created as a tourist product with a goal of presenting island's heritage in an attractive way, it serves its purpose well and the autheticity will not be a subject of further discussion in this paper.

9 Zrinka Ettinger Starčić, Underwater archaeological sites; Radmila Matejčić and Marijan Orlić, Rezultati prve faze hidroarheoloških istraživanja u cresko-losinjskim vodama. Arheološka istraživanja na otocima Cresu i Losinju. Znanstveni skup, Mali Losinj, II.-13. listopada $1979(\mathrm{Za}-$ greb: Hrvatsko arheološko društvo, 1982), I61-169; Marijan Orlić, Podmorsko arheološko nalazište Ilovik. Arbeološka istraživanja na otocima Cresu i Lošinju. Znanstveni skup, Mali Lošinj, II.-I3. listopada I979 (Zagreb: Hrvatsko arheološko društvo, 1982), 153-159; Irena Radić Rossi (ed.), Archeologia subacque in Croazia. Studi e ricerche (Venezia: Memorie Mediterranee, 2006).

Io SOURCE , Registar kulturnih dobara, Ministarstvo kulture Repubilke Hrvatske http://www.min-kulture.hr/default.aspx?id=3I; Radić Rossi, Irena ed. Archeologia subacque in Croazia. Studie ricerche. Venezia: Memorie Mediterranee, 2006.

I In the Municipal museum of Biograd remains of a trade ship from the i6th century, sunken in the vicinity are displayed. 
al means were allocated for the purchase of these concessions for the destination. Fort this reason diving locations also included the sites that this measure does not apply to.

The case of Montenegro has pointed towards different problems. Although the underwater archaeology of its coast is not thoroughly researched, ${ }^{\mathrm{I2}}$ there are sites of Bigovica and Maljevik that are attractive enough to be included in the tourist product. However, the legislative frame of protection of underwater heritage in MOntenegro is not strong enough to protect the heritage sites from looting, and even illicit trade of looted finds. Therefore, in the frame of the project, a special communication and information protolol had to be established to protect the providers of the diving-cultural tourist products from being recognized as illegal visitors and potential threat for heritage. Fortunately, a project partnership included a collaborators already being familiar with the situation and also collaborating with institutions for the protection of law and order.

Upon solving afore mentioned problems, a new cultural trail has been designed, uniting destinations along the eastern Adriatic coast: Izola, Mali Lošinj, Prvić and Budva. Although the cultural trails are expected to connect the existing historical trails, the creation of new ones is allowed in such cases as in this project, when they enable the promotion of the heritage ${ }^{\mathrm{I} 3}$ and ensure the sustainability for the local community, based on the cultural tourism.

Partner consortium continued the work on the project and developed a variety of activities like networking, educational workshops, market research in order to conceptualize, develop and promote new tourism product. All these goals are in line with an ICOMOS Internation-

I2 The most complete oveview is published in Karović, Gordana. »Podvodna arheološka nalazišta crnogorskog podmorja." Godišnjak Pomorskog muzeja u Kotoru LV-LVI (2008): 425-45 I.

I3 ICOMOS. "Listina o kulturnih poteh." Doktrina 2: Mednarodne listine in dokumenti ICOMOS, uredil: Jovo Grobovšek, (Ljubljana: Združenje ICOMOS/SI, 2008), 29-44 al Charter for Cultural Tourism, ${ }^{14}$ including three main and interdependent elements - tourists, heritage and local population. However, we must point out some other obstacles that were overcame during the project.

Local community was adressed through different educational activities and media promotion in order to get acquainted with the project and to consider collaboration. Educational workshops and several individual contacts were implemented in all destinations. However, the response from the local community was slow and weak but once the local community was reached they have helped in the process of promotion, as was noticed by the interest for the inclusion in the platform from destinations and providers that were not included in the project.

When considering tourists, and especially in the field of cultural tourism, there is a basic rule that a tourist has to have a positive experience. The problems begin when we start targeting tourists. At the beginning of the project, the main ide was that new products will attract the so called cultural tourists, that are highly motivated, but also have other positive characteristics, all connected with the financial side of the sustainability of the tourism market, ${ }^{15}$ in our case of the local community. A specific product, combining heritage with diving, had to involve a different kind of tourists - diving tourists. Analysys of their characteristics have shown that diving tourists only in part share similar characteristics with cultural tourists. That is why a compromise had to be made before packaging by including a large but not very specific type of tourists - mostly families, instead of tipical divin gor typical cultural tourists.

This has impacted a final stage of packaging. Since products had to be appealing to a quite large group with not necessarily similar interests, new contents had to be added to products. We have decided to overcome this problem

I4 ICOMOS, »Mednarodna listina o kulturnem turizmu « in Doktrina I: Mednarodne listine ICOMOS, ed. Jovo Grobovšek (Ljubljana: združenje ICOMOS/SI, I999), 6I-67.

I5 Ted Silberberg, »Cultural tourism and business opportunities «, 363. 
by creating at least two packages per destination, for both experienced and non experienced divers. Besides, all the packages had to include diving in heritage sites, visits to museums but also diving in attractive natural sites or they had to offer specific themathic contents to integrate all contents, such as underwater photography or similar.

\section{Conclusion}

International charter on cultural tourism from considered tourism as a valuable factor in the protection and conservation of natural and cultural heritage, which can comprise the economic elements of the heritage and use them by raising funds, educating the community and influencing the market policy. It is also an integral part of many national and regional economies, as it is important for development. ${ }^{16}$

By connecting the concepts of $\gg$ underwater heritage « and »tourism «, project ATAS managed to create a platform for the promotion of new products was created, which comprises tourism and leisure services with a strong focus on cultural and natural content and culture, that extends the awareness of its existence through tourism and its offer. ${ }^{17}$ On the other side, it created an international network of different institutions with a goal of a broader promotion of involved destinations. On the local level it enabled the creation of synergies within the cultural and tourism sector, with a focus on the SME thus enabling them to widen their offer, extend the season and have a more sustainable results.

\section{Povzetek}

Projekt ATAS - Antične pasti jadranskega morja je rezultat sodelovanja štirih različnih projektnih partnerjev iz Hrvaške, Črne gore in Slovenije. Partnerstvo je vključevalo različne profile, kot so lokalna uprava, univerza, hotel in potapljaški klub , z dvema glavnima podizvajalcema, enim s področja vodenja projektov in drugim s področja maketinga. Glavni cilj projekta je bil vzposta-

i6 Zrinka Mileusnić, »Cultural tourism and cultural tourists«, I04108 .

17 SOURCE 7 http://adriadiving.com viti mrežo standardiziranih turističnih produktov s poudarkom na podvodni dediščini Jadrana. Vzpostavljena je bila mreža novih turističnih produktov, ki bodo trženi prek skupne platforme, s ciljem lažje promocije in doseganja večjega števila potencialnih uporabnikov. Poleg tega sta bila projektna cilja tudi diverzifikacija lokalne turistične ponudbe in podaljšanje turistične sezone. Oblikovanje turističnih proizvodov na podlagi potapljaškega turizma je bilo nadgrajeno s celovito promocijo podvodne dediščine. Ta cilj je obsegal tako arheološko dediščino in situ kot tudi promocijo in predstavitev premične dediščine iz podvodnih najdišč, ki so prikazani v muzejih ali drugih institucijah. V prispevku predstavljamo glavne cilje in rezultate projekta, vendar tudi opozarjamo na potencialne ovire z vidika kulturnega in dediščinskega turizma.

\section{Summary}

Project ATAS - Ancient Traps of Adriatic Sea is the result of collaboration of four different project partners from Croatia, Montenegro and Slovenia. Partnership included different profiles, such as local government, university, hotel and a diving club with two main subcontractors, one from the field of project management and the other from the field of maketing. The main objective of the project was to establish a network of standardised tourist products with focus on underwater heritage of Adriatic. The network of new tourist products, makteted through the common platform, was created to facilitate the promotion and to reach greater number of potential users. The other aim of the project was diversification of the local tourist offer and the extension of the tourist season. The formation of tourism products based on the diving tourism was upgraded by the comprehensive promotion of underwater heritage. This objective comprised both archaeological heritage in situ, as well as the promotion and presentation of the movable heritage from underwater sites displayed in museums or other institutions. This paper presents the main project objectives and results, but also reminds of the potential obstacles from the perspective of the cultural and heritage tourism.

\section{Bibliography}

Ettinger Starčić, Zrinka. Underwater archaeological sites of the Losinj Archipelago, Mali Lošinj, 2013. 
ICOMOS. »Listina o interpretaciji in predstavitvi območij kulturne dediščine.« Doktrina 2: Mednarodne listine in dokumenti ICOMOS, uredil: Jovo Grobovšek, (Ljubljana: Združenje ICOMOS/SI, 2008), 45-53.

ICOMOS. »Listina o kulturnih poteh.« Doktrina 2: Mednarodne listine in dokumenti ICOMOS, uredil: Jovo Grobovšek, (Ljubljana: Združenje ICOMOS/SI, 2008), 29-44.

ICOMOS, »Mednarodna listina o kulturnem turizmu « in Doktrina I: Mednarodne listine ICOMOS, ed. Jovo Grobovšek (Ljubljana: združenje ICOMOS/SI, 1999), 6I-67.

ICOMOS, »Mednarodna listina o ohranjanju in obnovi spomenikov in spomeniških območij (Beneška Listina) in Doktrina I: Mednarodne listine ICOMOS, ed. Jovo Grobovšek (Ljubljana: združenje ICOMOS/SI, 1999), 25-28.

ICOMOS, »Mednarodna listina o ohranjanju in upravljanju arheološke dediščine (Lausannska listina) « in Doktrina I: Mednarodne listine ICOMOS, ed. Jovo Grobovšek (Ljubljana: združenje ICOMOS/SI, I999), 45-50.

Karović, Gordana. »Podvodna arheološka nalazišta crnogorskog podmorja.« Godišnjak Pomorskog muzeja u Kotoru LVLVI (2008): 425-45I.

Lazar, Irena, (ed.). Project AS. Archaeology for all. Revival of the Archaeological park Simonov zaliv. Project Manual. Koper: Založba Univerze na Primorskem, 2016.

Lazar, Irena. »Short description of the project and project collaborators. « In Lazar, Irena (ed.). Project AS. Archaeology for all. Revival of the Archaeological park Simonov zaliv. Project Manual. Koper: Založba Univerze na Primorskem (2016): 8-15.

Lazar, Irena, Ravnik, Mateja, Šmid, Katarina. »New contents fort he visitors and tourists - heritage trails.« in Lazar, Irena (ed.). Project AS. Archaeology for all. Revival of the Archaeological park Simonov zaliv. Project Manual. Koper: Založba Univerze na Primorskem (2016): 166-183.

Lazar, Irena, Mileusnić Zrinka. »Projekt AS in arheologija kot kulturni turizem.« Studia Universitatis Hereditati $3 / \mathrm{I}$, Založba Univerze na Primorskem (2015): 75-85.

Matejčić, Radmila, and Orlić Marijan. Rezultati prve faze hidroarheoloških istraživanja u cresko-lošinjskim vodama. Arheološka istraživanja na otocima Cresu i Lošinju. Znanstveni skup, Mali Lošinj, II.-I3. listopada 1979. Zagreb: Hrvatsko arheološko društvo (1982): I6I-I69.

Mileusnić, Zrinka. »Cultural tourism and cultural tourists - basic concepts. $\ll$ in Lazar, Irena (ed.). Project AS. Archaeology for all. Revival of the Archaeological park Simonov zaliv. Project Manual. Koper: Založba Univerze na Primorskem (2016): IO4-IO8.

Mileusnić, Zrinka, »The Project AS and archaeology as a cultural tourism. $\ll$ in Lazar, Irena (ed.). Project AS. Archaeology for all. Revival of the Archaeological park Simonov zaliv. Project Manual. Koper: Založba Univerze na Primorskem (2016): 16-17.

Orlić, Marijan. »Podmorsko arheološko nalazište Ilovik. Arheološka istraživanja na otocima Cresu i Lošinju «. Znanstveni skup, Mali Lošinj, II.-I3. listopada I979. Zagreb: Hrvatsko arheološko društvo, I982: 153-159.
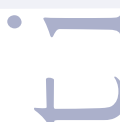

6

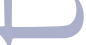

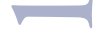
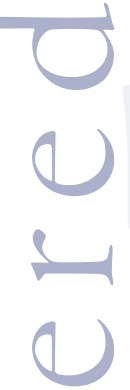

(n)

adić Rossi, Irena ed. Archeologia subacque in Croazia. Studi e ricerche. Venezia: Memorie Mediterranee, 2006.

Richards, Greg. »Production and consumption of European Cultural Tourism《. Annals of Tourism Research 23/2 (1996): 26I-283.

Role of Museums in Education and Cultural Tourism Development: Policy Brief. UNESCO (2012), Kyev.

Silberberg, Ted. »Cultural Ttourism and business opportunities for museums and 
heritage sites «. Tourism Management 16/5 (I995): 36I-365.

\section{Internet sources}

SOURCE I https://ec.europa.eu/easme/en/ ancient-traps-adriatic-sea (I.5.2017)

SOURCE 2 http://www.unesco.org/new/ en/culture/themes/underwater-culturalheritage/200I-convention/ (I.5.2017)

SOURCE 3 Manual for Activities directed at Underwater Cultural Heritage. Eds. Thijs J. Maarleveld, Ulrike Guérin, Barbara Egger. UNESCO publications (2013). http://www.unesco.org/new/en/culture/ themes/underwater-cultural-heritage/ publications-resources/publications/ (1.5.2017)

SOURCE 4 Register nepremične kulturne dediščine, Ministrstvo za kulturo, Republika Slovenija http://giskd6s.situla. org/giskd/ (1.5.2017)

SOURCE 5 Registar kulturnih dobara, Ministarstvo kulture Repubilke Hrvatske http://www.min-kulture.hr/default. aspx? $\mathrm{id}=31$ (1.5.2017)

SOURCE 6 https://www.swimtrek.com/ (I.5.2017)

SOURCE 7 http://adriadiving.com/ 